\title{
PENGARUH KOMISARIS INDEPENDEN, KOMITE AUDIT, CORPORATE SOCIAL RESPONSIBILITY, STRUKTUR MODAL DAN KINERJA KEUANGAN TERHADAP NILAI PERUSAHAAN SEKTOR PERTAMBANGAN YANG TERDAFTAR DI BURSA EFEK INDONESIA PERIODE TAHUN 2016-2019
}

\author{
Natrion, ST, SE., M.Ak \\ Sri Rahmawati \\ natrbach@gmail.com, rahmawatisri867@gmail.com
}

Fakultas Ekonomi dan Bisnis, Universitas Satya Negara Indonesia

\begin{abstract}
ABSTRAK
Nilai Perusahaan merupakan kekuatan tawar-menawar saham dipasar modal, dimana semakin tinggi nilai perusahaan akan semakin baik dalam menjalankan operasional perusahaan. Tujuan dari penelitian ini adalah untuk mengetahui adanya pengaruh antara Komisaris Independen, Komite Audit, Corporate Social Responsibility, Struktur Modal dan Kinerja Keuangan terhadap Nilai Perusahaan Sektor Pertambangan yang terdaftar di Bursa Efek Indonesia Periode Tahun 2016-2019.

Desain penelitian yang digunakan yaitu desain penelitian kausal. Populasi yang digunakan dalam penelitian ini adalah Sektor Pertambangan yang terdaftar di Bursa Efek Indonesia Periode Tahun 2016-2019. Teknik pengambilan sampel menggunakan teknik purpose sampling. Metode anlisis data Analisis Linier Berganda. Pengujian yang digunakan yaitu Statistik Deskriptif, Uji Asumsi Klasik, Pengujian Hipotesis yang terdiri dari Uji t dan Uji F, dan Uji Koefisien Determinasi.

Dari hasil analisis data, dapat ditarik kesimpulan Komisaris Independen tidak berpengaruh terhadap Nilai Perusahaan, Komite Audit berpengaruh negatif terhadap Nilai Perusahaan, Corporate Social Responsibility tidak berpengaruh terhadap Nilai Perusahaan, Struktur Modal dan Kinerja Keuangan berpengaruh secara signifikan terhadap Nilai Perusahaan.
\end{abstract}

Kata kunci :Komisaris Independen, Komite Audit, corporate social responsibility, Struktur Modal, Kinerja Keuangan, Nilai Perusahaan.

\section{PENDAHULUAN}

Pada hakikatnya setiap perusahaan memiliki strategi dan tujuan tertentu dalam mempertahankan Nilai Perusahaan. Nilai Perusahaan adalah pandangan atau persepsi investor mengenai bagaimana pencapaian kesuksesan manajemen dalam mengelola perusahaan, dimana ditanggungjawabkan kepada manajer yang sering dikaitkan pada harga saham. Nilai Perusahaan adalah nilai / sesuatu terpenting bagi perusahaan dan sering dikaitkan dengan haarga saham, karena dengan meningkatnya Nilai Perusahaan akan disertai dengan meningkat harga saham yang dapat mencerminkan pada meningkatnya suatu kemakmuran bagi

Jurnal Ilmiah Akuntansi dan Ekonomi Volume. 6 Nomor. 2, Agustus 2021 Hal. 120 
para pemilik perusahaan. Pasar modal tentu bukan hanya melihat kinerja perusahaan tetapi juga pada bagaimana prospek / rencana perusahaan dimasa mendatang dengan adanya peningkatan Nilai Perusahaan (Silvia Indrarini,2019).

Nilai Perusahaan yang meningkat adalah suatu pencapaian yang menjadi tujuan bagi pemilik karena dengan meningkatnya Nilai Perusahaan, maka kesenjangan bagi pemilik juga terus berkembang dan ini merupakan suatu tanggung jawab bagi manajer sebagai agent yang dipercayakan oleh pemilik perusahaan dalam mengoperasionalkan perusahaan (Sudiyanto, 2012).

Peningkatan Nilai Perusahaan dapat dipengaruhi oleh adanya Komisaris Independen. Dimana dengan keberadaan Komisaris Independen ini dapat meningkatkan kualiats perusahaan, dengan memiliki jumlah Komisaris Independen yang maksimal hal ini dapat membantu dalam melakukan fungsi pengawasan dan mengarahkan tata kelola perusahaan dengan baik. Disamping itu juga akan meningkatkan ketepatan dalam pengawasan terhadap Dewan Direksi, sehingga akan menwakili kepentingan bersama dibandingkan dengan kepentingan minoritas perusahaan.

Peningkatan Nilai Perusahaan lainnya juga dibarengi dengan adanya Komite Audit di perusahaan. Komite Audit adalah prosentase total anggota Komite Audit diluar perusahaan dengan keseluruhan Komite Audit. Dengan kinerja Komite Audit yang baik dalam hal melindungi kepentingan bagi pemegang saham minoritas tentu hal ini akan mengurangi konflik yang terjadi di perusahaan, sehingga informasi tentang perusahaan terutama yang bersifat keuangan yang disajikan kepada pihak terkait dapat dipercayakan dan diharapkan mampu meningkatan Nilai Perusahaan.

Peningkatan Nilai Perusahaan lainnya yaitu menerapkan CSR, yang diartikan sebagai rencana yang dilakukan perusahaan untuk menujukkan citra di hadapan publik dengan menggerakkan program yang bersifat kemanusiaan baik dalam lingkup internal maupun eksternal. Lingkup eksternal dengan adanya patnership yang mengikut sertakan pemangku kepentingan dalam hal menujukkan keterkaitan perusahaan baik masyarakat maupun lingkungan sekitarnya. Sedangkan lingkup internal perusahaan mampu menghasilkan produksi secara baik, pencapaian laba perusahaan, dan kesejahteraan karyawan (Achmad Lamo Said, 2018). Dalam penelitian ini diukur dengan menggunakan tingkat pengungkapan CSR di annual report perusahaan yang dinyatakan dalam CSR Indeks dimana daftar pengungkapan menggunakan ISO 26000 (International Organization for Standardization 26000) yang meliputi : Tata Kelola Organisasi, HAM, Ketenagekerjaan, Lingkungan, Praktik Operasi yang Adil, Kosumen dan Pengembangan Masyarakat (Achmad Lamo Said, 2018).

Kemudian, peningkatan Nilai Perusahaan juga bisa dilihat pada Struktur Modal. Dimana jika perusahaan menambah jumlah utang (modal dari luar ) perusahaan untuk perluasan usaha tentu akan meningkatnya harga saham perusahaan. Dan apabila terjadi peningkatan nilai perusahaan yang diakibatkan oleh bertambahnya utang perusahaan selama Struktur Modal dibawah titik kewajaran. Maka, hal ini mampu meningkatkan Nilai Perusahaan karena keutungan yang di dapat dari bertambah nya utang itu sendiri masih lebih besar dari pengorbanan yang dikeluarkan perusahaan. Dalam mengukur Struktur Modal 
ini peneliti menggunakan rasio keuangan $D E R$ dimana rasio ini digunakan untuk membandingkan pendanaan yang di keluarkan dengan hutang terhadap pendanaan yang dikeluarkan perusahaan dengan tujuan mampu meningkatkan Nilai Perusahaan.

Selain itu, peningkatan Nilai Perusahaan tercermin juga pada Kinerja Keuangan dalam menghasilkan laba bersih atas aktiva perusahaan, dimana hal ini merupakan dasar acuan pengambilan keputusan investor dalam berinvestasi. Jika dalam suatu perusahaan mampu menghasilkan laba yang besar, maka perusahaan akan menarik banyak investor karena Kinerja Keuangan perusahaan menjukkan kualitas nilai yang baik. Seperti pada Perusahaan Pertambangan PT Bukit Asam Tbk dimana pada akhir periode tahun 2018 perusahaan ini mampu menghasilkan laba sebersar Rp. 5,02 Triliun sebab adanya kenaikan pendapatan usaha dari penjualan ekspor sebesar Rp 2,244 Triliun. Laba bersih ini naik dibandingkan pada tahun 2017 dan target laba bersih tahun 2018 yang ditetapkan perusahaan (Krisantus de Rosari Binsasi, 2019). Dalam mengukur Kinerja Keuangan ini peneliti menggunakan rasio $R O A$, dimana rasio ini digunakan untuk mengetahui laba atas aktiva yang digunakan perusahaan. Pada dasarnya Peningkatan laba juga menjadi salah satu tujuan dalam meningkatkan Nilai Perusahaan.

Dalam penelitian ini yang menjadi objek penelitian adalah perusahaan Sektor Pertambangan yang terdaftar di BEI karena keberadaannya berpengaruh besar terhadap perekonomian di Indonesia. Dimana Indonesia merupakan negara penghasil sumber daya alam yang potensial untuk meningkatkan kualitas hidup masyarakat dan meningkatkan sumber pendapatan Nasional. Dengan adanya sektor pertambangan ini diharapkan bisa membantu laju perkembangan negara karena mampu meningkatkan kualitas sumber daya alam yang ada. Penelitian ini bertujuan untuk mencari pengaruh Komisaris Independen, Komite Audit, CSR, Struktur Modal dan Kinerja Keuangan terhadap Nilai Perusahaan Sektor Pertambangan. Penelitian ini merupakan acuan dari penelitian sebelumnya oleh Fika Fadiacha dan Rahmawati Hanny Y (2016) dengan judul "Pengaruh Good Corporate Governance, Corporate Social Responsibility dan Kinerja Keuangan Terhadap Nilai Perusahaan". Namun dalam penelitian yang dilakukan saat ini terdapat perbedaan yang terletak pada objek penelitian, tahun penelitian dan adanya penambahan vaiabel bebas / vaiabel independen.

\section{LANDASAN TEORI}

\section{Laporan Keuangan}

Laporan Keuangan merupakan alat yang digunakan untuk mengukur kualitas suatu perusahaan dalam mengelola keuangan yang digunakan dalam pengeluaran biaya operasional perusahaan. Analisis laporan keuangan adalah Peralatan (tools) untuk memahami laporan keuangan dan bukan sarana membagi suatu akun ke akun lainnya karena membutuhkan wawasan luas mengenai aspek keuangan (David Wijaya,2017).

\section{Nilai Perusahaan}

Nilai Perusahaan merupakan nilai / sesuatu terpenting bagi perusahaan karena dengan mengembangkan nilai perusahaan akan disertai dengan meningkat harga 
saham yang dapat mencerminkan pada meningkat nya suatu kemakmuran bagi para pemegang saham (Silvia Indrarini,2019).

\section{Komisaris Independen}

Komisaris Independen adalah Salah satu struktur tata kelola perusahaan yang memiliki fungsi dalam melakukan pengawasan perusahaan untuk membuat suatu laporan keuangan dan mencegah adanya controlling shareholder yang dapat merugikan pemilik minoritas (Silvia Indrarini,2019).

\section{Komite Audit}

Komite Audit adalah struktur tata kelola perusahaan yang dibentuk oleh Dewan Komisaris, dimana memiliki fungsi dan tanggung jawab untuk membantu Dewan Komisaris di perusahaan (Silvia Indrarini,2019).

\section{Corporate Social Responsibility (CSR)}

$C S R$, bisa diartikan sebagi usaha perusahaan dalam menujukkan citra di hadapan publik dengan menggerakkan program yang bersifat kemanusiaan baik dalam lingkup internal maupun eksternal. (Achmad Lamo Said,2018).

\section{Struktur Modal}

Struktur Modal adalah Penggambaran dari bentuk rasio perusahaan yaitu antara modal yang berasal dari hutang jangka panjang dengan modal sendiri yang digunakan untuk pembiayaan operasional suatu perusahaan (Irham Fahmi,2015).

\section{Kinerja Keuangan}

Kinerja Keuangan adalah Hasil akhir dari laporan keuangan yang dijadikan sebagai ketetapan oleh manajemen dalam suatu perusahaan untuk mencapai tujuan tertentu secara praktis sehingga menghasilkan keputusan yang baik (Fika Fiadicha dan Rahmawati Hanny Y,2016).

\section{Kerangka Pemikiran}

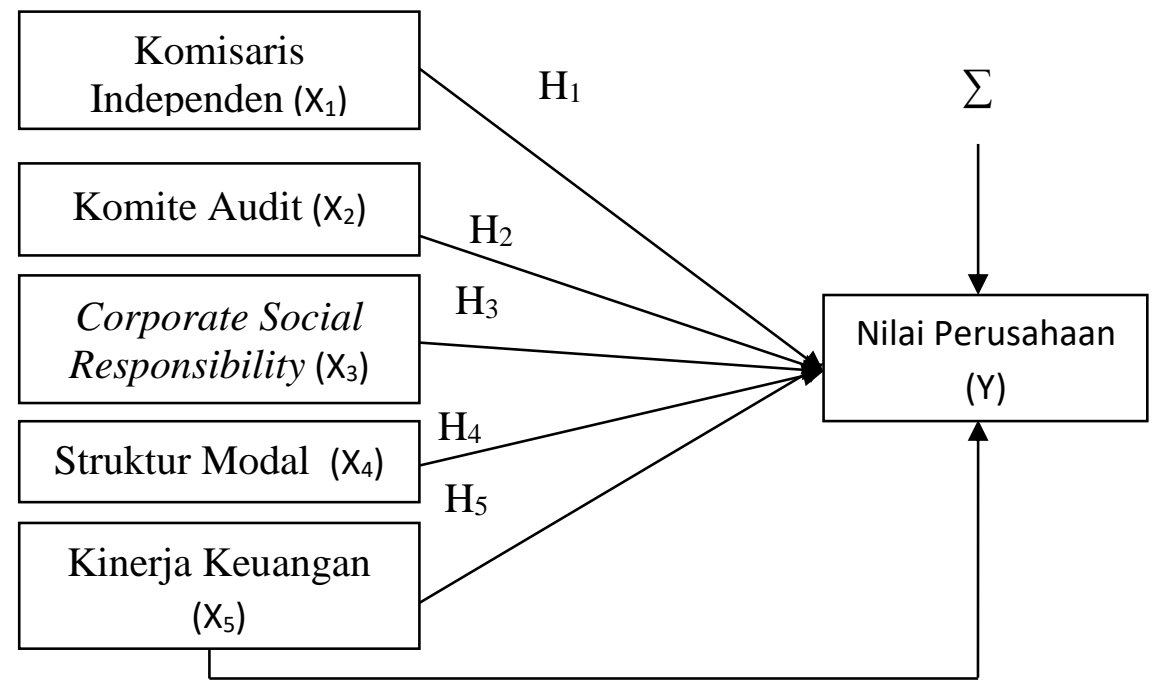


Gambar 1.1

Kerangka Pemikiran

\section{Hipotesis}

$\mathrm{H}_{1} \quad$ : Komisaris Independen berpengaruh terhadap Nilai Perusahaan

$\mathrm{H}_{2} \quad$ : Komite Audit berpengaruh terhadap Nilai Perusahaan

$\mathrm{H}_{3}$ : Corporate Social Responsibility berpengaruh terhadap Nilai Perusahaan.

$\mathrm{H}_{4} \quad$ : Struktur Modal berpengaruh terhadap Nilai Perusahaan.

$\mathrm{H}_{5} \quad$ : Kinerja Keuangan berpengaruh terhadap Nilai Perusahaan.

$\mathrm{H}_{6} \quad$ : Komisaris Independen, Komite Audit, Corporate Social Responsibilit, Struktur Modal dan Kinerja Keuangan berpengaruh terhadap Nilai Perusahaan.

\section{METODOLOGI PENELITIAN}

\section{Desain Penelitian, Jenis Data dan Metode Pengumpulan data}

Desain penelitian yang digunakan dalam penelitian ini adalah Penelitian Kausal. Penelitian ini menggunakan jenis data kuantitatif dari data sekunder. Metode pengumpulan data pada penelitian ini adalah Studi Kepustakaan, Dokumentasi dan Observasi. Data penelitian ini diambil melalui website Bursa Efek Indonesia yaitu www.idx.co.id

\section{Populasi dan Sampel}

Dalam penelitian ini yang menjadi populasi adalah seluruh Perusahaan Sektor Pertambangan yang terdaftar di Bursa Efek Indonesia pada Periode Tahun 20162019. Metode pengambilan Sampel menggunakan Purposive Sampling, dimana digunakan dengan membuat kriteria-kriteria tertentu yang harus dipenuhi. Adapun kriteria sampel dalam penelitian ini adalah sebagai berikut : (1) Perusahaan sektor Pertambangan yang terdaftar di Bursa Efek Indonesia pada periode 2016-2019. (2) Perusahaan yang menerbitkan laporan keuangan dan laporan tahunan secara lengkap secara berturut-turut selama tahun pengamatan. (3) Perusahaan yang memperoleh laba secara berturut-turut selama tahun pengamatan.

\section{Variabel Penelitian dan Definisi Operasional Variabel}

Pada penelitian Variabel dependen : nilai perusahaan, sedangkan variabel independen : Komisaris Independen, Komite Audit, Corporate Social Responsiility, Struktur Modal dan Kinerja Keuangan.

\section{Nilai Perusahaan (Y)}

Nilai Perusahaan adalah pandangan investor mengenai bagaimana pencapaian kesuksesan management dalam mengelola sumber daya yang ada di perusahaan, dimana merupakan bentuk tanggung jawab management kepada pemegang saham, yang sering dihubungkan dengan harga saham. (Silvia Indrarini,2019) Dalam 
penelitian ini Nilai Perusahaan diukur dari Price to Book Value (PBV), rumus sebagaiberiut:

$P B V=\frac{\text { Harga Saham }}{\text { Book Value }} \times 100 \%$

\section{Komisaris Independen (X1)}

Komisaris Independen adalah struktur tata kelola perusahaan yang memiliki fungsi dalam melakukan pengawasan perusahaan untuk membuat suatu laporan keuangan dan mencegah adanya controlling shareholder yang dapat merugikan pemilik minoritas (Silvia Indrarini, 2019). Adapun rumus Komisaris Independen (Ardyanto dan Kurnia,2013) sebagai berikut :

Komisaris Independen $=\frac{\text { Jumlah komisaris independen }}{\text { Total Anggota Dewan Komisaris }} \times 100 \%$

\section{Komite Audit (X2)}

Komite Audit adalah struktur tata kelola perusahaan yang dibentuk dan memiliki tanggung jawab kepada Dewan Komisaris untuk membantu melaksanakan tugas dan fungsi Dewan Komisaris di suatu perusahaan (Silvia Indrarini,2019). Adapun rumus Komite Audit dalam penelitian ini, (Reviani dan Sudantoko, 2012) yaitu :

Komite Audit $=\frac{\sum \text { anggota Komite Audit diluar perusahaan }}{\sum \text { anggota Komite Audit }} \times 100 \%$

\section{Corporate Social Responsibility (CSR) (X3)}

Corporate Social Responsibility (CSR) diukur dengan menggunakan tingkat pengungkapan $C S R$ pada laporan tahunan perusahaan yang dinyatakan dalam $C S R$ Indeks dimana daftar pengungkapan menggunakan ISO 26000 (International Organization for Standardization 26000) yang meliput: tata kelola organisasi, Hak Asasi Manusia, Ketenagakerjaan, Lingkungan, Praktik Operasi yang Adil, Konsumen dan Pengembangan Masyarakat (Achmad Lamo, 2018). Dimana dalam penelitian ini diberi skor 0 jika tidak diungkapkan dan diberi skor 1 jika diungkapkan (Susanto dan Ardini,2017). Berikut ini rumus penelitian adalah:

$\operatorname{CSRIj}=\frac{\sum \mathrm{xij}}{\mathrm{nJ}} \times 100 \%$

\section{Struktur modal (X4)}

Menurut Issabela Permata Dhani dan A.A Gde Satia Utama (2017) Struktur Modal adalah proporsi pendanaan dengan hutang perusahaan. Dalam penelitian Struktur Modal diukur dengan Debt to Equity Ratio. Rasio ini dapat dirumuskan : 
Debt to Equity Ratio $(D E R)=\frac{\text { Total Hutang }}{\text { Total Modal }} \times 100 \%$

\section{Kinerja Keuangan (X5)}

Hasil akhir dari laporan keuangan yang dijadikan sebagai ketetapan oleh manajemen dalam suatu perusahaan untuk mencapai tujuan tertentu secara praktis sehingga menghasilkan keputusan yang baik. (Fika Fiadicha dan Rahmawati Hanny Y, 2016). Adapun rumusnya adalah :

Return On Assets $=\frac{\text { Net Income }}{\text { Net Assets }} \times 100 \%$

\section{Metode Analisis Data}

\section{Statistik Deskriptif}

Menurut Ghozali (2016) Statistik Deskriptif digunakan untuk mendeskripsikan suatu data dengan hasil seperti Nilai Minimum, Maksimum, Rata-Rata (Mean), Standar Deviasi, Sum, Range, Kurtosis dan Skewness (Kemencengan Distribusi).

\section{Uji Asumsi Klasik}

\section{Uji Normalitas}

Menurut Ghozali (2016) Uji Normalitas ini digunakan untuk mengetahui apakah dalam variabel residual memiliki distribusi normal. Dalam Uji Normalitas ini menggunakan Analisis Statistik Non-Parametik Uji Kolmogorow Smirnov, dimana data berdistribusi normal jika nilai signifikasi $>0,05$.

\section{Uji Multikolonieritas}

Menurut Ghozali (2016) Uji Multikolonieritas bertujuan untuk menguji apakah model regresi ditemukan adanya korelasi antara variabel bebas (independen). Untuk mendeteksi data tidak mengalami Multikolinearitas adalah Nilai tolerance $>0,1$ dan nilai $\mathrm{VIF}<10$.

\section{Uji Autokorelasi}

Menurut Ghozali (2016) Uji Autokorelasi bertujuan untuk menguji apakah dalam model regresi linier terdapat korelasi antara kesalahan penggangu pada periode $t$ dengan kesalahan periode - $\mathrm{t}$ (sebelumnya). Dalam mendeteksi data tidak mengalami Autokorelasi menggunakan uji Durbin-Watson (DW) $\mathrm{du}<\mathrm{dw}<(4-\mathrm{du})$

\section{Uji Heteroskedastisitas}

Menurut Ghozali (2016) uji heteroskedastisitas bertujuan untuk menguji apakah dalam model regresi terjadi ketidaksamaan variance dari residual satu pengamatan ke pengamatan lain. cara menguji ada tidaknya heteroskedastisitas yaitu menggunakan uji glejser. Untuk mendeteksi data tidak mengalami Heteroskedastisitas ini dengan cara mengamati angka sign $>0,05$. 


\section{Analisis Regresi Linier Berganda}

Analisis Regresi Linier Berganda adalah analisis yang digunakan untuk menganalisis adanya hubungan antara beberapa variabel independen (X) terhadap variabel dependen (Y). Model Persamaan Analisis Regresi Linier Berganda, yaitu: $Y=a+b_{1} X_{1}+b_{2} X_{2}+b_{3} X_{3}+b_{4} X_{4}+b_{5} X_{5}+e$

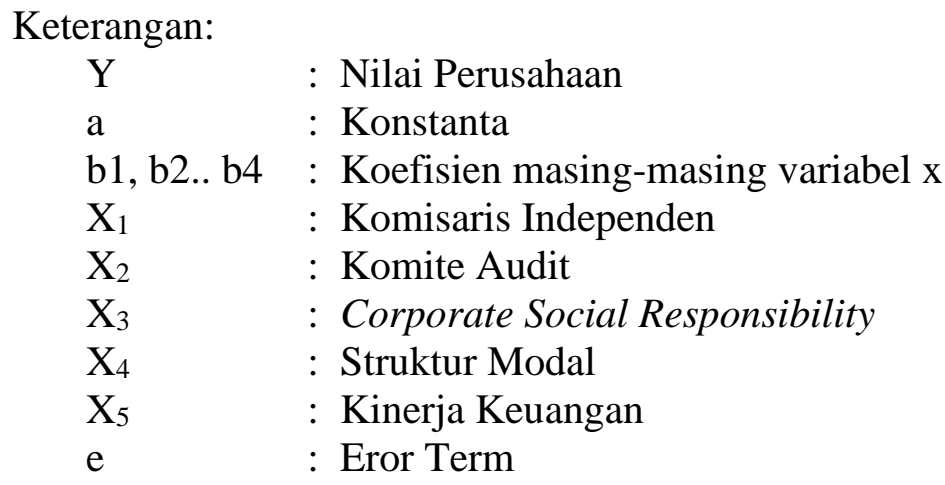

\section{Pengujian Hipotesis}

\section{Uji Parsial (Uji t)}

Menurut Ghozali (2016) Uji t digunakan untuk mengetahui pengaruh variabel independen secara individual terhadap variabel dependen. Untuk mengetahui pengaruh uji $\mathrm{t}$ terhadap variabel independen sebagai berikut : Jika thitung $>\mathrm{t}$ tabel, dan nilai signifikansi jika nilai probabilitas $<0,05$, maka Ha diterima dan Ho ditolak.

\section{Uji Simultan (Uji F)}

Menurut Ghozali (2016) uji F digunakan untuk mengetahui pengaruh keseluruhan variabel independen terhadap variabel dependen secara bersama. Untuk mengetahui pengaruh uji $\mathrm{F}$ terhadap variabel independen adalah Jika

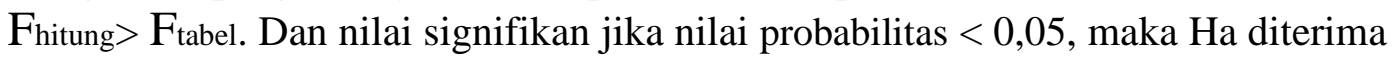
dan Ho ditolak.

Uji Koefisien Determinasi $\left(\mathrm{R}^{2}\right)$

Koefisien Determinasi $\left(\mathrm{R}^{2}\right)$ digunakan untuk mengetahui adanya kemampuan variabel independen menjelaskan variabel dependen. Nilai Koefisien Determinasi adalah diantara 0 (nol) sampai dengan 1 (satu). (Ghozali ,2016).

\section{ANALISIS HASIL}

\section{Statistik Deskriptif}

Statistik Deskriptif ini digunakan untuk mengetahui Nilai Minimum, Nilai Maksimum, Nilai Mean dan Standar Deviasi. Dimana variabel bebas ini terdiri dari Komisaris Independen, Komite Audit, CSR, Struktur Modal dan Kinerja 
Keuangan dan variabel terikat adalah Nilai Perusahaan. Adapun hasil Statistik Deskriptif dengan bantuan SPSS versi 22 :

Tabel 4.3 . Hasil Uji Statistik Deskriptif

\begin{tabular}{|l|r|r|r|r|r|}
\multicolumn{1}{l|}{ Descriptive Statistics } \\
& $\mathrm{N}$ & Minimum & Maximum & \multicolumn{1}{c|}{ Mean } & \multicolumn{1}{c|}{$\begin{array}{c}\text { Std. } \\
\text { Deviation }\end{array}$} \\
\hline KOMISARIS_INDEPENDEN & 52 & 25,00 & 66,67 & 38,8446 & 8,92218 \\
KOMITE_AUDIT & 52 & 33,33 & 66,67 & 57,6938 & 12,98051 \\
CORPORATE_SOCIAL__ & 52 & 62,07 & 89,66 & 76,3929 & 7,33575 \\
RESPONSIBILITY & 52 & 11,87 & 338,31 & 76,5752 & 56,81631 \\
KINERJA_KEUANGAN & 52 &, 22 & 45,56 & 10,8206 & 10,03521 \\
STRUKTUR_MODAL & 52 & 24,80 & 791,14 & 177,0669 & 167,38818 \\
NILAI_PERUSAHAAN & 52 & & & & \\
Valid N (listwise) & & & \\
\hline
\end{tabular}

Sumber : hasil output SPSS versi 22

\section{Uji Asumsi Klasik}

\section{Uji Normalitas}

Tabel 4.4. Hasil Uji Normalitas

One-Sample Kolmogorov-Smirnov Test

\begin{tabular}{|ll|r|}
\hline & & $\begin{array}{c}\text { Unstandardized } \\
\text { Residual }\end{array}$ \\
\hline Normal Parameters & & 52 \\
& Mean &, 0000000 \\
Most Extreme Differences & Std. Deviation & 3,61898416 \\
& Absolute &, 083 \\
& Positive &, 083 \\
Test Statistic & Negative &,- 047 \\
Asymp. Sig. (2-tailed) & &, 083 \\
\hline
\end{tabular}

Sumber : hasil output SPSS versi 22

Berdasarkan tabel 4.4, Uji Normalitas ini menggunakan analisis Statistik Non-Parametik Uji Kolmogorow Smirnov. Dimana nilai signifikan adalah 0,200 yang menunjukkan signifikan > 0,05, maka data dikatakan berdistribusi normal.

\section{Uji Multikolinearitas}

Tabel 4.5. Hasil Uji Multikolinearitas

Coefficients $^{\mathrm{a}}$

\begin{tabular}{|c|c|c|c|c|c|c|c|}
\hline \multirow[b]{2}{*}{ Model } & \multicolumn{2}{|c|}{$\begin{array}{c}\text { Unstandardized } \\
\text { Coefficients }\end{array}$} & \multirow{2}{*}{\begin{tabular}{|c}
$\begin{array}{c}\text { Stand } \\
\text { ardize } \\
\mathrm{d} \\
\text { Coeffic } \\
\text { ients }\end{array}$ \\
Beta
\end{tabular}} & \multirow[b]{2}{*}{$\mathrm{T}$} & \multirow[b]{2}{*}{ Sig. } & \multicolumn{2}{|c|}{ Collinearity Statistics } \\
\hline & $\mathrm{B}$ & $\begin{array}{l}\text { Std. } \\
\text { Error }\end{array}$ & & & & Tolerance & VIF \\
\hline (Constant) & 7,961 & 12,662 & & ,629 &, 533 & & \\
\hline
\end{tabular}




\begin{tabular}{|c|c|c|c|c|c|c|c|}
\hline $\begin{array}{l}\text { KOMISARIS } \\
\text { INDEPENDEN }\end{array}$ & 152 & 836 & ,020 & 182 & 857 & 894 & 1,118 \\
\hline KOMITE_AUDIT & $-1,912$ & 666 &,- 335 & $-2,871$ & ,006 & ,758 & 1,320 \\
\hline $\begin{array}{l}\text { CORPORATE_ } \\
\text { SOCIAL } \\
\text { RESPONSSIBILITY }\end{array}$ & 230 & 1,311 & ,018 & 176 & 861 & 973 & 1,028 \\
\hline $\begin{array}{l}\text { STRUKTUR_ } \\
\text { MODAL }\end{array}$ & 878 & 224 & 490 & 3,912 & ,000 & 659 & 1,517 \\
\hline $\begin{array}{l}\text { KINERJA } \\
\text { KEUANGĀN }\end{array}$ & 2,876 & 414 & ,790 & 6,943 & ,000 & ,798 & 1,253 \\
\hline
\end{tabular}

Sumber : hasil output SPSS versi 22

Berdasarkan hasil tabel 4.5, secara keseluruhan variabel menujukkan nilai Tolerance $>$ 0,1 dan nilai Variance Inflating Factor (VIF) $<10$. Artinya dalam model regresi ini tidak terjadi adanya korelasi antar sesama variabel bebas, maka dapat dikatakan data tidak mengalami Multikolinearitas.

\section{Uji Autokorelasi}

Tabel 4.6. Hasil Uji Autokorelasi Model Summary ${ }^{b}$

\begin{tabular}{|l|c|r|r|r|r|}
\hline Model & $\mathrm{R}$ & $\mathrm{R}$ Square & $\begin{array}{c}\text { Adjusted R } \\
\text { Square }\end{array}$ & $\begin{array}{c}\text { Std. Error of the } \\
\text { Estimate }\end{array}$ & Durbin-Watson \\
\hline 1 &, $719^{\mathrm{a}}$ &, 518 &, 464 & 109,85324 & 1,849 \\
\hline
\end{tabular}

Sumber : hasil output SPSS versi 22

Berdasarkan tabel 4.6, Kriteria Durbin-Watson (DW) adalah du<dw $<(4-d u)$, Sehingga didapat hasil $1,7694<1,849<2,2306$, Jadi dapat ditarik kesimpulan bahwa data tidak mengalami Autokorelasi.

\section{Uji Heteroskedastisitas}

Tabel 4.7. Hasil Uji Heteroskedastisitas Coefficients $^{a}$

\begin{tabular}{|c|c|c|c|c|c|}
\hline \multirow[b]{2}{*}{ Model } & \multicolumn{2}{|c|}{$\begin{array}{l}\text { Unstandardized } \\
\text { Coefficients }\end{array}$} & \multirow{2}{*}{$\begin{array}{c}\begin{array}{c}\text { Standardized } \\
\text { Coefficients }\end{array} \\
\text { Beta }\end{array}$} & \multirow[b]{2}{*}{$\mathrm{T}$} & \multirow[b]{2}{*}{ Sig. } \\
\hline & $\mathrm{B}$ & Std. Error & & & \\
\hline (Constant) &,- 231 & ,225 & & $-1,028$ & ,309 \\
\hline KOMISARIS_INDEPENDEN & ,001 & ,003 & ,077 &, 529 &, 599 \\
\hline KOMITE_AUDIT &, 000 & ,002 & ,018 & ,125 & ,901 \\
\hline $\begin{array}{l}\text { CORPORATE_SOCIAL_ } \\
\text { RESPONSIBILITY }\end{array}$ & ,005 & ,003 & ,218 & 1,536 & ,131 \\
\hline STRUKTUR_MODAL & ,001 &, 000 & ,237 & 1,514 & ,137 \\
\hline KINERJA_KEUANGAN &, 003 & ,003 & , 167 & 1,090 & ,281 \\
\hline
\end{tabular}

Sumber : hasil output SPSS versi 22

Berdasarkan hasil tabel 4.7, dimana hasil dari semua variabel independen menujukkan nilai signifikan > 0,05, maka dapat disimpulkan data tidak mengalami Heteroskedastisitas.

Tabel 4.8 


\begin{tabular}{|c|c|c|c|c|c|}
\hline \multicolumn{6}{|c|}{ Coefficients $^{a}$} \\
\hline \multirow[b]{2}{*}{ Model } & \multicolumn{2}{|c|}{$\begin{array}{l}\text { Unstandardized } \\
\text { Coefficients }\end{array}$} & \multirow{2}{*}{$\begin{array}{c}\begin{array}{c}\text { Standardized } \\
\text { Coefficients }\end{array} \\
\text { Beta }\end{array}$} & \multirow[b]{2}{*}{$\mathrm{T}$} & \multirow[b]{2}{*}{ Sig. } \\
\hline & $\mathrm{B}$ & Std. Error & & & \\
\hline (Constant) & 92,898 & 159,162 & &, 584 &, 562 \\
\hline $\begin{array}{l}\text { KOMISARIS } \\
\text { INDEPENDEN }\end{array}$ & 1,086 & 1,919 &, 060 &, 566 &, 574 \\
\hline KOMITE_AUDIT & $-3,294$ & 1,450 &,- 246 & $-2,272$ & ,028 \\
\hline $\begin{array}{l}\text { CORPORATE_SOCIAL } \\
\text { _ RESPONSIBILITY }\end{array}$ &,- 611 & 2,383 &,- 027 &,- 256 & ,799 \\
\hline STRUKTUR_MODAL & 1,651 & ,321 &, 591 & 5,137 &, 000 \\
\hline KINERJA_KEUANGAN & 11,249 & 1,889 & 670 & 5,956 &, 000 \\
\hline
\end{tabular}

Sumber : hasil output SPSS versi 22

\section{Analisis Regresi Linier Berganda}

Berdasarkan hasil tabel 4.8, maka dapat disimpulkan untuk Analisis Regresi

Linear Berganda adalah sebagai berikut :

$Y=92,898+1,086 X_{1}-3,294 X_{2}-0,611 X_{3}+1,651 X_{4}+11,249 X_{5}+e$

\section{Pengujian Hipotesis}

\section{Uji Parsial (Uji t)}

Berdasarkan tabel 4.8, maka dapat disimpulkan (1) Komisaris Independen tidak berpengaruh terhadap Nilai Perusahaan. Hal ini dapat dilihat dari thitung $0,566<2,01290$ dan nilai signifikan 0,574 >0,05 sehingga Ho1 diterima. (2) Komite Audit berpengaruh negatif terhadap Nilai Perusahaan. Hal ini dapat dilihat dari nilai thitung $-2,272>2,01290$ dan nilai signifikan $0,028<0,05$ sehingga Ha2 diterima. (3) CSRy tidak berpengaruh terhadap Nilai Perusahaan. Hal ini dapat dilihat bahwa nilai thitung $-0,256<2,01290$ dan nilai signifikan 0,799 > 0,05 sehingga Ho3 diterima. (4) Struktur Modal berpengaruh terhadap Nilai Perusahaan. Hal ini dapat dilihat dari nilai thitung 5,137> 2,01290 dan nilai sig $0,000<0,05$, sehingga $\mathrm{Ha} 4$ diterima. (5) Kinerja Keuangan berpengaruh terhadap nilai perusahaan. Hal ini dapat disimpulkan bahwa thitung 5,956 2,01290 dan nilai signifikan $0,000<0,05$ sehingga Ha5 diterima.

\section{Uji Simultan (Uji F)}

Tabel 4.9. Hasil Uji Simultan (Uji F) ANOVA $^{\mathrm{a}}$

\begin{tabular}{|l|r|r|r|r|r|}
\hline Model & Sum of Squares & Df & Mean Square & F & Sig. \\
\hline Regression & 582798,418 & 5 & 116559,684 & 9,659 &, $000^{\mathrm{b}}$ \\
Residual & 543048,048 & 45 & 12067,734 & & \\
Total & 1125846,465 & 50 & & & \\
\hline
\end{tabular}

Sumber : hasil output SPSS versi 22

Berdasarkan tabel 4.9 Secara Simultan Komisaris Independen, Komite 
Audit, CSR, Struktur Modal dan Kinerja Keuangan berpengaruh signifikan terhadap Nilai Perusahaan. Hal ini dapat dilihat dari nilai Fhitung 9,659> 2,41 Ftabel dan nilai signifikan sebesar $0,000<0,05$.

\section{Uji Koefisien Determinasi}

Tabel 4.10. Hasil Uji Koefisien Determinasi Model Summary

\begin{tabular}{|l|r|r|r|c|}
\hline Model & $\mathrm{R}$ & R Square & $\begin{array}{c}\text { Adjusted R } \\
\text { Square }\end{array}$ & $\begin{array}{c}\text { Std. Error of the } \\
\text { Estimate }\end{array}$ \\
\hline 1 &, $719^{\mathrm{a}}$ &, 518 &, 464 & 109,85324 \\
\hline
\end{tabular}

Sumber : hasil output SPSS versi 22

Berdasarkan tabel 4.10, dari hasil uji Koefisien Determinasi yang dilihat dari nilai Adjusted $R$ Square sebesar 0,464 atau 46,4\%. Yang artinya variabel dependen (Nilai Perusahaan) dapat dijelaskan oleh variabel independen, seperti Komisaris Independen, Komite Audit, CSR, Struktur Modal dan Kinerja Keuangan. Sedengkan sisanya sebesar 53,6\% dijelaskan oleh variabel lain diluar model penelitian, seperti Debt to Asset Ratio, Return On Equity, Inflasi, Kepemilikan Institusional, Kualitas Audit.

\section{PEMBAHASAN}

Berdasarkan analisa diatas, maka dapat dijelaskan sebagai berikut :

\section{Pengaruh Komisaris Independen Terhadap Nilai Perusahaan}

Hasil penelitian menujukkan bahwa Komisaris Independen tidak berpengaruh terhadap Nilai Perusahaan. Hal ini dapat disimpulkan bahwa thitung 0,566< 2,01290 dan nilai signifikan 0,574 > 0,05 sehingga Ha1 ditolak dan Ho1 diterima.

Dalam penelitian Komisaris Independen ini hasilnya menunjukkan tidak berpengaruh terhadap Nilai Perusahaan. Itu berarti keberadaan Komisaris Independen dalam perusahaan bukan merupakan faktor pendukung dalam meningkatkan Nilai Perusahaan. Hasil penelitian ini didukung oleh Intan Mutiasari (2018) yang menjelaskan bahwa Komisaris Independen tidak berpengaruh terhadap Nilai Perusahaan.

\section{Pengaruh Komite Audit Terhadap Nilai Perusahaan}

Hasil penelitian menunjukkan bahwa variabel Komite Audit berpengaruh negatif terhadap Nilai Perusahaan. Hal ini dapat dilihat dari nilai thitung $-2,272>2,01290$ dan nilai signifikan 0,028<0,05 sehingga $\mathrm{H}_{2}$ diterima dan $\mathrm{H}_{\mathrm{o}}$ ditolak.

Dalam penelitian ini Komite Audit menunjukkan hasil berpengaruh negatif terhadap Nilai Perusahaan. Hal ini menjelaskan, bahwa semakin banyak jumlah Komite Audit, maka akan semakin menurun Nilai Perusahaan. Karena semakin banyak jumlah Komite Audit, maka akan semakin banyak pengendalin dan pengawasan yang dilakukan, hal ini akan menyulitkan manajemen untuk mengambil keputusan karena banyaknya pertimbangan yang diambil dari masing-masing pendapat komite audit. Sehingga akan berpengaruh pada nilai 
perusahaan. Hasil penelitian ini sejalan dengan penelitian Fika Fiadicha dan Rahmawati Hanny Y (2016) dimana hasilnya menujukkan bahwa Komite Audit berpengaruh terhadap Nilai Perusahaan

\section{Pengaruh Corporate Social Responsibility Terhadap Nilai Perusahaan}

Hasil penelitian CSR tidak berpengaruh terhadap Nilai Perusahaan. Hal ini dapat dilihat dari nilai thitung $-0,256<2,01290$ dan nilai signifikan $0,799>$ 0,05 sehingga $\mathrm{H}_{a} 3$ ditolak dan $\mathrm{H}_{03}$ diterima.

Dalam penelitian $C S R$ ini hasilnya menunjukkan tidak berpengaruh terhadap nilai perusahaan. Itu artinya penerapan $C S R$ dalam suatu perusahaan tidak menjamin citra perusahaan akan meningkat dihadapan para investor. Penelitian ini sejalan dengan penelitian Fika Fiadicha dan Rahmawati Hanny Y (2016) yang menjelaskan bahwa $C S R$ tidak berpengaruh terhadap Nilai Perusahaan.

\section{Pengaruh Struktur Modal Terhadap Nilai Perusahaan}

Hasil penelitian Struktur Modal yang diproksikan oleh Debt to Equity Ratio berpengaruh terhadap Nilai Perusahaan. Hal ini dapat disimpulkan bahwa thitung 5,137 > 2,01290 dan nilai signifikan 0,000 < 0,05 sehingga Ha4 diterima dan $\mathrm{H}_{04}$ ditolak.

Dalam penelitian ini menujukkan hasil Struktur Modal yang diproksikan oleh $D E R$ berpengaruh terhadap Nilai Perusahaan. Yang artinya kemampuan perusahaan dalam mengelola modal untuk operasional perusahaan menjadi salah satu fakor meningkatnya nilai perusahaan, karena investor mempercayakan investasinya di perusahaan yang bisa mengelola keuangan dengan baik. Penelitian ini didukung oleh I Putu Agus Rizaldi, Ni Putu Yuria Mendra, Luh Gde Novitasari (2019) yang menjelaskan bahwa Struktur Modal yang diproksikan oleh $D E R$ berpengaruh terhadap Nilai Perusahaan.

\section{Pengaruh Kinerja Keuangan Terhadap Nilai Perusahaan}

Hasil penelitian Kinerja Keuangan yang diproksikan oleh Return On Asset berpengaruh terhadap Nilai Perusahaan. Hal ini dapat disimpulkan bahwa thitung 5,956 $>$ 2,01290 dan nilai signifikan $0,000<0,05$ sehingga $\mathrm{H}_{5}$ diterima dan Ho5 ditolak.

Dalam penelitian ini menujukkan hasil Kinerja Keuangan yang diproksikan oleh Return On Asset berpengaruh terhadap Nilai Perusahaan. Karena kemampuan perusahaan dalam mengelola keuangan perusahaan dengan baik akan berdampak pada kepercayaan publik terhadap perusahaan tersebut terutama investor dalam berinvestasi. Penelitian ini sejalan penelitian I Putu Agus Rizaldi, Ni Putu Yuria Mendra, Luh Gde Novitasari (2019) yang menjelaskan bahwa Kinerja Keuangan yang diproksikan oleh Return On Asset berpengaruh terhadap Nilai Perusahaan.

\section{KESIMPULAN}

Kesimpulan penelitian ini adalah (1) Komisaris Independen tidak berpengaruh terhadap Nilai Perusahaan.(2) Komite Audit berpengaruh negatif terhadap Nilai 
Perusahaan.(3) Corporate Social Responsibility tidak berpengaruh terhadap Nilai Perusahaan.(4) Struktur Modal berpengaruh terhadap Nilai Perusahaan. (5) Kinerja Keuangan berpengaruh terhadap nilai perusahaan.(6) Secara Simultan Komisaris Independen, Komite Audit, Corporate Social Responsibility, Struktur Modal dan Kinerja Keuangan berpengaruh signifikan terhadap Nilai Perusahaan.

\section{SARAN}

Saran untuk penelitian ini adalah (1) Untuk penelitian selanjutnya, diharapkan bisa menambahkan variabel independen lainnya seperti Debt to Asset Ratio, Return On Equity, Inflasi, Kepemilikan Institusional, Kualitas Audit. (2) Untuk Perusahaan, penelitian ini diharapkan bisa membantu perusahaaan dalam meningkatkan kualitas nilai perusahaan agar bisa bersaing dengan perusahaan lain dan dapat menarik para investor untuk menanamkan investasinya. (3) Untuk investor, penelitian ini diharapkan bisa membantu investor untuk mengetahui pengukuran nilai perusahaan, sehingga investor dapat mengambil keputusan dalam berinvestasi.

\section{DAFTAR PUSTAKA}

Ardyanto, F. D., \& kurnia. (2013). Pengaruh Mekanisme Gcg Dan Pelaporan Csr Terhadap Nilai Perusahaan Di BEI. Jurnal Dinamika Manajemen (Vol. 2). Surabaya: Sekolah Tinggi Ilmu Ekonomi Indonesia (STIESIA).

Andaria,Siti.2018. Pengaruh Good Corporate Governance, Corporate Social Responsibility, Kinerja Keuangan dan Kebijakan Dividen Terhadap Nilai Perusahaan. In SKRIPSI.

Anwar, Mokhamad.2019. Dasar-Dasar Manajemen Keuangan Perusahaan. Kencana, Bandung.

Binsasi,Krisantus de Rosari, 2019. "Bukit Asam (PTBA) bukukan laba bersih Rp 5,02 triliun pada 2018, berikut pendorongnya". https://investasi.kontan.co.id/news/bukit-asam-ptba-bukukan-lababersih-rp-502-triliun-pada-2018-berikut-pendorongnya. Diakses pada tanggal 16 April 2021 Pukul 21.30.

Dangnga, Muh. Taslim dan M. Ikhwan Maulana Haeruddin, 2019. Kinerja Keuangan Perbankan : Upaya untuk Menciptakan Sistem Perbankan yang Sehat. Makasar : Pustaka Taman Ilmu.

Dewi,Inggi Rovita, Siti Ragil Handayani dan Nila Firdausi Nuzula. (2014) Pengaruh Struktur Modal Terhadap Nilai Perusahaan (Studi pada Sektor Pertambangan yang terdaftar di BEI Periode 2009-2012). In Jurnal Administrasi Bisnis (JAB) Vol.17 No.1 Desember 2014.

Dhani, Isabella Permata dan A.A Gde Satia Utama. (2017). Pengaruh Pertumbuhan Perusahaan, Struktur Modal dan Profitabilitas terhadap Nilai Perusahaan. In Jurnal Riset Akuntansi dan Bisnis Airlangga Vol. 2 No.1.

Fahmi, Irham. 2015. Pengantar Manajemen Keuangan Teori dan Soal Jawab. Bandung: Alfabeta. 
Fiadicha, Fika dan Rahmawati Hanny Y.(2016). Pengaruh Good Corporate Governance, Corporate Social Responsibility, dan Kinerja Keuangan Terhadap Nilai Perusahaan. In Jurnal Akuntasni Manajerial.

Ghozali, Imam. 2016. Aplikasi Analisis Multivariate Dengan Program SPSS.

Semarang : Badan Penerbit Universitas Diponegoro.

Indrarini, Silvia.2019.Nilai Perusahaan Melalui Kualitas Laba (Good Corporate \& Kebijakan Perusahaan). Scopindo Media Pustaka, Surabaya.

Mutiasari, Intan. (2018). Pengaruh Good Corporate Governance, Kebijakan Deviden dan Pengungkapan Corporate Social Responsibility terhadap Nilai Perusahaan pada Perusahaan Pertambangan di Bursa Efek Indonesia Periode 2015-2017. In Skripsi Akuntansi.

Peraturan Otoritas Jasa Keuangan Nomor 55/POJK.04/2015. Tentang Pembentukan dan Pedoman Pelaksanaan Kerja Komite Audit. www.ojk.go.id/id/regulasi/peraturanojk/POJKNomor55.POJK.04.2015. diakses pada 28 April 2021.

Rizaldi, I Putu Agus, Ni Putu Yuria Mendra dan Luh Gde Novitasari.(2019). Pengaruh Corporate Social Responsibility, Profitabilitas, dan Struktur Modal Terhadap Nilai Perusahaan di Bursa Efek Indonesia. In Jurnal Riset Akuntansi VOL.9 NO.2 September 2019.

Reviani, Dinni dan Sudantoko, Djoko, 2012. Pengaruh Struktur Kepemilikan, Ukuran Perusahaan, dan Corporate Governance Terhadap Manajemen Laba. STIE Bank BPD Jateng. ISSN 1441-1497 Volume: 9 No.1.

Said, Achmad Lamo.2018. Corporate Social Responsibility Dalam Perspektif Governance.Deepublish, Yogyakarta.

Sugiono, Arief dan Edy Untung.2016. Panduan Praktis Dasar Analisa Laporan Keuangan.. PT Grasindo, Jakarta.

Sugiyono. 2015. Metode Penelitian Kuantitatif dan $R \&$ D . Alfabeta, Bandung.

Soegiarto, Eddy.2018. Metedologi Penelitian dan Penulisan Ilmiah. Indocamp, Tanggerang Selatan.

Susanto, C.M., dan Ardini L. (2017). Pengaruh Good Corporate Governance dan Corporate Social Responsibility Terhadap Nilai Perusahaan. Jurnal ilmu dan Riset Akuntansi, 5(7).1-17.

Wijaya, David. 2017. Manajemen Keuangan Konsep dan Penerapannya.

www.idx.co.id PT Grasindo, Anggota IKAPI, Jakarta.

www.bi.go.id/id/statistik/informasi-kurs/jisdor/Default.aspx. diakses pada 24 Mei 2021 Pukul 20.30. 